1 Penn AS. Myoglobin and myoglobinuria. In: Vinken PJ, Bruyn GW, eds. Handbook of clinical neurology. Amsterdam, Oxford: North Holland, 1979:259-85.

2 Penn AS. Myoglobinuria. In: Engel AG, Banker BQ, eds. Myology. New York: McGraw-Hill, 1986:1785-805

3 Bartlett JC, Rooney TW, Hunter JC. Rhabdomyolysis of the upper extremities associated with weight lifting: report of a case. 7 Am Osteopath Assoc 1985;85:646-8.

4 Di Mauro S, Bresolin N. Phosphorylase deficiency. In: Engel AG, Banker BQ, eds. Myology. New York: McGraw-Hill, 1986:1585-601.

5 Pedersen P. Rabdomyolvse i forbindelse med bodybuilding. Ugeskr Laeger 1986;148:1680-1.

(Accepted 18 November 1987)

Clinica Neurologica II, Università degli Studi di Torino, Torino, Italy

C DORIGUZZI, MD, assistant, department of neurology

L PALMUCCI, MD, research vice head, department of neurology

T MONGINI, MD, research fellow, department of neurology

E ARNAUDO, MD, fellow in neurology

Clinica Neurologica, Centro Dino Ferrari, Università degli Studi di Milano, Milano, Italy

L BET, MD, research fellow, department of neurology

N BRESOLIN, MD, research assistant, department of neurology

Correspondence and requests for reprints to: $\mathrm{Dr} C \mathrm{C}$ Doriguzzi, Clinica Neurologica II, Via Cherasco 15, 10126, Torino, Italy.

\section{Blackwater fever caused by Plasmodium vivax infection in the acquired immune deficiency syndrome}

Blackwater fever is usually associated with malaria caused by Plasmodium falciparum infection in susceptible subjects. It is not associated with othe parasites in man. ${ }^{\prime}$ We describe a case of blackwater fever caused by $P$ vivax infection in a patient with the acquired immune deficiency syndrome (AIDS)

\section{Case report}

A 37 year old African woman was admitted with fever, diarrhoea, and vomiting. Two years previously she had complained of intermittent attacks of fever of several months' duration, which had been followed by oral candidiasi and genital herpes. She had been treated with ketoconazole and ampicillin with some improvement, though she had continued to lose weight. She then developed cervical lymphadenopathy; biopsy showed non-specific lymphadenitis. A week before admission she had developed fever, diarrhoea, and vomiting. At first she was thought to have malaria, but she did not improve despite treatment with chloroquine. Typhoid fever was then suspected, but her symptoms did not respond to ampicillin.

On examination she looked ill and was mildly anaemic and dehydrated, but not jaundiced. Blood pressure was normal, and she was tender over the right flank. Haemoglobin concentration was $110 \mathrm{~g} / \mathrm{l}$, white cell count $8.2 \times 10^{9} / 1$, and erythrocyte sedimentation rate $45 \mathrm{~mm}$ in the first hour. Her glucose-6-phosphate dehydrogenase activity was not measured. A film of the peripheral blood did not show malaria parasites. She had antibodies to the human immunodeficiency virus (HIV) on enzyme linked immunosorbent assay (ELISA). Blood was not cultured for viruses or bacteria. No parasites or salmonellas were isolated from her stools. Her urine was sterile on culture, though it contained protein.

She was treated with intravenous fluid replacement, ampicillin $500 \mathrm{mg}$ six hourly intravenously, and antiemetics. Three days later she was still feverish and had become delirious and confused. She seemed more anaemic and was jaundiced, though there was no evidence of a bleeding diathesis. She was tachypnoeic with bronchopneumonia, and a chest $x$ ray film suggested infection with Pneumocystis carinii. Her urine was dark, and the output was reduced. No red cells were seen in the urine, but benzidine and guaicum tests showed free haemoglobin. Her haemoglobin concentration was $92 \mathrm{~g} / \mathrm{l}$, the white cell and platelet counts were normal, and the erythrocyte sedimentation rate was $40 \mathrm{~mm}$ in the first hour. A film of the peripheral blood showed that about $95 \%$ of the red cells had been invaded by $P$ vivax. Analysis of the urine showed a protein concentration of $1 \mathrm{~g} / \mathrm{l}$ but no red or white cell casts were seen.

Blackwater fever due to infection with $P$ vivax was diagnosed, and she was treated with chloroquine, primaquine, and high doses of co-trimoxazole fo suspected $P n$ carinii pneumonia. She died the same day, and permission for necropsy was refused.

\section{Comment}

This may be the first report of blackwater fever due to $P$ vivax infection, which is less common than $P$ falciparum in east Africa. Over two years the patient had become progressively more immunocompromised by HIV infection and her symptoms had been mistakenly attributed to causes other than vivax malaria. Though the prevalence of subjects with antibodies to HIV is high in central Africa and parts of east Africa, there have been no reports that malaria is more severe or more common among patients with AIDS. ${ }^{2}$ It is worth noting that she had severe parasitic invasion at the time of haemolysis, which is uncommon. Furthermore, only about $2 \%$ of red cells are usually invaded by parasites in patients with malaria caused by $P$ vivax, increasing to over $5 \%$ if the patient is immunocompromised; in this case $95 \%$ were affected. Pn carinii pneumonia is an unusual complication of the disease. The diagnosis of blackwater fever itself might be questioned, particularly as glucose-6-phosphate dehydrogenase activity was not measured. This would be to miss the point that fatal infection with $P$ vivax occurred in a patient with AIDS, and it is unfortunate that permission for necropsy was refused.

1 Manson-Bahr PEC, Apted FIC. Manson's tropical diseases. 18th ed. London: Baillière Tindall,

2 Biggar JR. The clinical features of HIV infection in Africa. Br Med f 1986;293:1453-4.

(Accepted 25 August 1987)

Uganda Cancer Institute, PO Box 3935, Kampala, Uganda

EDWARD KATONGOLE-MBIDDE, MMED, MRCP, acting director

CECIL BANURA, MB, DPH, senior research officer

ALEXANDRIA KIZITO, $\mathrm{MB}$, CHB, clinical associate

Correspondence to: Dr Katongole-Mbidde.

\section{Adult epiglottitis due to Vibrio vulnificus}

Adult epiglottitis is rare and characterised by dysphagia, upper airway obstruction, and toxaemia; it may progress rapidly to fatal asphyxiation. ${ }^{12}$ We report on a man with $\beta$ thalassaemia major who developed acute epiglottitis and septicaemia due to Vibrio vulnificus. We know of no previous report of this organism causing epiglottitis.

\section{Case report}

A 22 year old man with $\beta$ thalassaemia major receiving regular transfusions and desferrioxamine presented to the casualty department with a sore throat, which had started several hours earlier. He had had a splenectomy when aged 8 and had been prescribed phenoxymethylpenicillin V $250 \mathrm{mg}$ twice daily prophylactically but had complied only occasionally. While in the casualty department he experienced difficulty in breathing and developed inspiratory stridor. He was unable to speak or swallow, and there was drooling of saliva. He had enlarged, discrete, mobile cervical glands, and one axillary gland was enlarged. The tonsils were enlarged and the throat inflamed and oedematous; his temperature was $39 \cdot 8^{\circ} \mathrm{C}$, pulse rate $100 / \mathrm{min}$, and blood pressure $110 / 70 \mathrm{~mm} \mathrm{Hg}$. The chest was clear on clinical and radiographic examination. Haemoglobin concentration was $9.9 \mathrm{~g} / \mathrm{l}$, white cell count (corrected for nucleated red cells) $55 \times 10^{9} / 1(81 \%$ neutrophils), and platelet count $301 \times 10^{9} / 1$. Acute epiglottitis was diagnosed provisionally and laryngoscopy performed under general anaesthesia. ${ }^{3} \mathrm{~A}$ large swollen, yet pale epiglottis was seen occluding the vocal cords. He was intubated with difficulty, and mechanical ventilation was started. He was started empirically on intravenous benzylpenicillin $1200 \mathrm{mg}$ four hourly and erythromycin $500 \mathrm{mg}$ six hourly.

The next day a Gram negative rod was isolated from a blood culture and throat swab. In view of this intravenous cefuroxime $1500 \mathrm{mg}$ eight hourly was substituted for erythromycin. The white cell count rose to $74 \times 10^{9} / 1$ (90\% neutrophils). Over the next 24 hours his condition improved but he remained feverish $\left(37 \cdot 5^{\circ} \mathrm{C}\right)$. Two days later laryngoscopy was repeated; the epiglottis was normal but the throat still inflamed. He was given a transfusion and chelation with desferrioxamine was continued. His condition stabilised well and he was extubated after 72 hours. He made satisfactory progress, continuing with intravenous antibiotics for a week before changing to oral phenoxymethylpenicillin $500 \mathrm{mg}$ six hourly.

We tried unsuccessfully to identify the Gram negative rod by inoculating the organism into Analytical Profile Index 20E. It was found to be indole and oxidase positive and to have a darting motility and was therefore suspected to be a vibrio. The identification procedure was repeated with $1 \%$ sodium chloride as suspending medium, and salicin peptone water was inoculated. Disc sensitivity tests to vibriostatic agent 0129 showed inhibition by discs at $10 \mu \mathrm{g}$ and $150 \mu \mathrm{g}$ strengths. The organism was identified as $V$ vulnificus based on its fermentation of lactose, mannitol, amygdalin, and salicin; positive results of tests for indele and oxidase; its motility; and its sensitivity to agent 0129 .

Closer questioning of the patient elicited a bizarre story. Three days before admission he had bought a large pet fish, and the plastic carrier bag containing it had been accidentally set alight by a cigarette. He had instinctively dived into the bag to rescue the fish and had burnt his thumb, which he then put in his mouth; 72 hours later he developed epiglottitis. 


\section{Comment}

Clinical infections caused by marine vibrios were reviewed by Blake $e t a l$, who reported pre-existing hepatic disease in 18 of 24 patients presenting with septicaemia, abrupt onset of symptoms, and skin lesions; four of the 18 had haemachromatosis, and one thalassaemia major. Our patient showed no abnormality on tests of liver function, and ferritin concentrations (1689 $\mu \mathrm{g} / \mathrm{l})$ were within acceptable limits. The bioavailability of iron has been implicated in infections caused by $V$ vulnificus. ${ }^{5}$

When carrying out biochemical tests it is worth remembering that a mobile rod positive for oxidase and indole should be tested in medium containing $1 \%$ sodium chloride, particularly if no fermentation reactions are noted initially.

1 Kander PL, Richards SH. Acute epiglottitis in adults. $\mathcal{F}$ Laryngol Otol 1977;91:295-302.

2 Hawkins DB, Miller AH, Sachs GB, Benz RT. Acute epiglottitis in adults. Laryngoscope 1973;83:1211-20.

3 Warner AJ, Finlay WE. Fulminating epiglottitis in adults. Anaesthesia 1985;40:348-52.

4 Blake PA, Michael MPH, Merson H, Weaver RE, Hollis DH, Heublein PC. Disease caused by a marine vibrio. $N$ Englf Med 1979;300:1-5.

5 Tison DL, Kelly MT. Vibrio species of medical importance. Diagn Microbiol Infect Dis 1984;2 263-76.

(Accepted 9 December 1987)

\section{North Middlesex Hospital, London N18 1QX}

SHAHEEN MEHTAR, MB, MRCPATH, consultant microbiologist LIETTA BANGHAM, $\mathrm{MB}, \mathrm{CHB}$, senior registrar in haematology

DEBORAH KALMANOVITCH, MB, FFARCS, senior registrar in anaesthetics MICHAEL WREN, FIMLS, chief medical laboratory scientific officer

Correspondence to: Dr Mehtar.

\section{Can patients with Refsum's disease safely eat green vegetables?}

Refsum's disease (heredopathia atactica polyneuritiformis) is caused by an inability to metabolise phytanic acid, which accumulates in adipose tissue and plasma. The clinical features include retinitis pigmentosa, anosmia, and neuropathy. Lowering the plasma phytanic acid concentration by restricting phytanic acid in the diet or by plasma exchange leads to improvement in the neuropathy.' Phytanic acid is formed from free phytol but not from phytol bound to chlorophyll, which is poorly absorbed. ${ }^{2}$ Hitherto, fruit and green vegetables have been excluded from the diet of patients with Refsum's disease because of lack of data on their free phytol content. This has reduced the diet's palatability and nutritional value and necessitated the use of vitamin supplements. To broaden the scope of the diet we introduced fruit and vegetables with high phytol but low free phytol content into the diet of a patient with Refsum's disease and assessed the effect of this new diet.

\section{Case report}

The patient was a 40 year old man. ${ }^{1}$ At diagnosis his plasma phytanic acid concentration had been $1.51 \mathrm{mmol} / \mathrm{l}$. From 1977 his diet had been low in phytanic acid and phytol. From 1982 his plasma phytanic acid concentration had been at or below $0.3 \mathrm{mmol} / 1$, and he had continued to improve clinically.

The amount of phytanic acid in extractable lipids in food was estimated.' To estimate free phytol lipids were extracted from dried food with chloroform and methanol $(2: 1 \mathrm{v} / \mathrm{v} 25 \mathrm{ml} / \mathrm{g}$ dried food $)$. An aliquot of the extract with an internal standard (methyl pentadecanoate, $0.1 \mathrm{ml}, 2.86 \mathrm{mmol} / \mathrm{l}$ ) was evaporated to dryness and redissolved in $0.2 \mathrm{ml} n$-hexane. The sample was analysed by gas-liquid chromatography using a $12 \mathrm{~m} \mathrm{BP10}$ fused silica capillary column, internal diameter $0.22 \mathrm{~mm}$; hydrogen was used as carrier gas at an inlet pressure of $41 \mathrm{kPa}$ and a split ratio of $40: 1$, with an isothermal oven temperature of $190^{\circ} \mathrm{C}$. The logarithm of retention time of phytol relative to methyl pentadecanoate is 0.5272 ; the phytol content of foods was calculated by reference to this external standard. Adding an aliquot of free phytol to foods free of phytol showed that recovery of phytol with this method was at least $85 \%$, with a minimum detection concentration of $2.517 \mu \mathrm{mol}$ phytol $/ \mathrm{kg}$ food (dry weight).

Between April 1984 and March 1985 the patient successively added seven groups of foods containing negligible amounts of free phytol to his diet so that by February 1985 he was eating food from all groups (table). His total daily intake of phytanic acid was less than $10 \mathrm{mg}$ a day except when he ate peanuts, when he took up to $30 \mathrm{mg}$ phytanic acid a day. Peanuts were subsequently excluded from the diet.

The patient's clinical condition remained unchanged during and after the study. Serial plasma concentrations of phytanic acid remained below $0.15 \mathrm{mmol} / \mathrm{l}$, concentrations in adipose tissue fell from $43.27 \mathrm{mmol} / \mathrm{kg}$ tissue in May 1983 to $12.82 \mathrm{mmol} / \mathrm{kg}$ tissue in January 1985 , and body weight remained in the range $77-80 \mathrm{~kg}$. The patient preferred the improved diet, which was nutritionally adequate without supplements.

\section{Comment}

Plasma and adipose tissue concentrations of phytanic acid did not rise when phytol bound to chlorophyll was added to the diet of this patient with Refsum's disease. Previous diets for such patients, though effective, have been restrictive; the new diet should improve palatability, compliance of patients, and nutritional value. Thus provided that their free phytol content is low, foods containing phytol bound to chlorophyll can be introduced into the diet of patients with Refsum's disease.

1 Gibberd FB, Billimoria JD, Goldman JM, et al. Heredopathia atactica polyneuritiformis (Refsum's disease). Acta Neurol Scand 1985;72:1-7.

2 Steinberg D. Phytanic acid storage disease (Refsum's disease). In: Stanbury JB, Wyngaarden JB Fredrickson DS, Goldstein JL, Brown MS, eds. The metabolic basis of inherited disease. 5th ed. New York: McGraw-Hill, 1985:731-47.

(Accepted 6 November 1987)

Departments of Medicine, Dietetics, and Lipid Biology, Westminster Hospital, London SW1

$S$ W COPPACK, BSC, MRCP, medical registrar

R EVANS, SRD, chief dietitian

F B GIBBERD, MD, FRCP, consultant neurologist

$M$ E CLEMENS, PHD, biochemist

J D BILLIMORIA, DSC, FRIC, professor of lipid biology

Correspondence and requests for reprints to: Dr Gibberd.

Phytanic acid and free phytol content of food ${ }^{\star}$

\begin{tabular}{|c|c|c|c|c|}
\hline & $\begin{array}{c}\text { Date } \\
\text { started }\end{array}$ & Examples of food & $\begin{array}{l}\text { Phytanic acid } \\
(\mu \mathrm{mol} / \mathrm{kg})\end{array}$ & $\begin{array}{l}\text { Free phytol } \\
(\mu \mathrm{mol} / \mathrm{kg})\end{array}$ \\
\hline \multirow[t]{3}{*}{ Cooked vegetables } & May 1984 & Spinach & $1 \cdot 3$ & $6 \cdot 4$ \\
\hline & & Leeks & Trace & 0 \\
\hline & & Asparagus & 0 & $2 \cdot 5$ \\
\hline \multirow[t]{4}{*}{ Pulses } & June 1984 & Peas & 0 & 0 \\
\hline & & Pease pudding & $3 \cdot 2$ & 0 \\
\hline & & Lentils & $19 \cdot 2$ & 0 \\
\hline & & Broad beans & $9 \cdot 6$ & $6 \cdot 7$ \\
\hline Raw vegetables & July 1984 & $\begin{array}{l}\text { Mixed salad (lettuce, mustard, cress, parsley, cucumber, green pepper, spring onion, white and red cabbage, bean } \\
\text { shoots, celery, watercress) }\end{array}$ & $14 \cdot 1$ & $6 \cdot 4$ \\
\hline \multirow{3}{*}{ Fresh fruit } & September 1984 & Apples & 0 & 0 \\
\hline & & Grapes & $9 \cdot 6$ & 0 \\
\hline & & Pears & 0 & 0 \\
\hline \multirow[t]{4}{*}{ Dried fruit } & November 1984 & Sultanas & $12 \cdot 8$ & 0 \\
\hline & & Raisins & $12 \cdot 8$ & 0 \\
\hline & & Currants & 0 & 0 \\
\hline & & Prunes & $35 \cdot 2$ & 0 \\
\hline Nuts & December 1984 & Roast peanuts & $1311 \cdot 8$ & 0 \\
\hline \multirow{3}{*}{ Tomatoes } & February 1985 & Purée & 0 & 0 \\
\hline & & Tinned & Trace & 0 \\
\hline & & Ketchup & $3 \cdot 2$ & 0 \\
\hline
\end{tabular}

* Samples of food were analysed in duplicate. Results are given for undried food. 